УДК 655.3.066(075.8)

\title{
КЛАСИФІКАЦІЯ ПОШКОДЖЕНЬ БАНКНОТ В ОБІГУ
}

๑ Т. Ю. Киричок, к.т.н., доцент, НТУУ «КПІ», Київ, Україна

В работе на основе анализа процессов, происходящих во время пребывания банкнот в обороте, а также факторов износа банкнот разработана классификация повреждений банкнот в результате износа. В качестве классификационных признаков выделены причины износа (по виду энергетического воздействия), систематичность и критичность повреждений, способ выявления (визуальный или аппаратный), локализацию, объект контроля, последствия воздействия и признаки, подлежащие контролю.

The defects of banknotes because of deterioration were classified as result of analyzing the both processes occurring during the circulation of banknotes as well as factors of banknotes' deterioration. It was suggested to consider the reasons of deterioration (by type of impact energy which causes deterioration), systematic and critical defects, method of detection (visual or hardware, etc.), location, object for control, generalized type and features to be monitored as a basic classification features.

The detailing of banknotes defects during deterioration was worked out to use it during the study of deterioration in order to optimize production processes and rational choice of materials for banknote production. The worked out classification of banknotes' defects gives the possibilities to systematize the information on banknotes defects and to take them into account during research.

\section{Постановка проблеми}

Питання зношування та пошкодження банкнот під час перебування в обігу є об'єктом досліджень науковців та фахівців центральних банків багатьох держав [1-3]. В Україні питання вилучення банкнот з обігу регулюються низкою нормативних документів [4, 5], що, зокрема, встановлюють пошкодження, котрі можуть бути підставою для вилучення банкнот з обігу. До таких пошкоджень належать пошкодження захисних елементів, механічні пошкодження різ- ного типу, загальне та локальне забруднення та зношування.

Активно проводяться дослідження, спрямовані на виявлення причин та наслідків зношування [6-8]. Аналіз показує, що шляхом оптимізації технологічних процесів виготовлення та раціонального вибору матеріалів можливе збільшення зносостійкості банкнот за рахунок підвищення стійкості банкнот до забруднень, загального зношування та, частково, механічних пошкоджень та пошкоджень захисних елементів [9-12]. 
Для оптимізації технологічних процесів та вибору матеріалів необхідно оцінювати вплив технологічних факторів на зносостійкість банкнотних відбитків. Дослідження останньої найчастіше проводять з використанням імітаторів зношування [13]. Однак, при цьому постає питання кореляції результатів, отриманих в імітаторах та в реальних умовах обігу, котре досі, фактично, не вирішено [8].

\section{Мета дослідження}

Метою даного дослідження було проведення аналізу та систематизація пошкоджень, які виникають в реальних умовах обігу банкнот.

\section{Результати проведених досліджень}

Банкноти належать до поліграфічної продукції, що перебуває в умовах інтенсивного використання, під час якого на банкноти діє низка факторів, що тою чи іншою мірою спричиняють пошкодження різного типу, котрі проявляються в зміні властивостей банкноти, внаслідок чого відбувається втрата (повна чи часткова) споживчих якостей.

Фактори зношування можуть діяти як протягом всього часу перебування банкноти в обігу, так і тимчасово (багаторазово чи одноразово), можуть впливати на банкноту як суцільно, так і локально, спричиняючи як загальне зношування та забруднення, так і локальні пошкодження, котрі проявляються в порушенні структурної цілісності та окремих забрудненнях.

Чинником зношування банкнот виступають біологічні (люди, мікроорганізми тощо) та небіологічні об'єкти (сортувальне обладнання, монети, з якими відбувається природний контакт під час обігу, а також довкілля в усіх проявах). Необхідно зазначити, що фактором найбільшого впливу на банкноти є люди, оскільки, основним чинником забруднення банкнот $є$ дотики пальців, що залишають відбитки, котрі з часом накопичуються та утворюють жовто-коричневий шар застарілого шкірного сала $[6,8]$. З'ясовано, що з $81 \%$ банкнот виводиться з обігу через забруднення, 9 \% - через механічні пошкодження, $5 \%$ - через сторонні написи (графіті), 4 \% - через загальне зношування, 1 \% - через пошкодження захисних елементів [14]. Такий поділ є достатньо схематичним, а пошкодження, що є причиною виведення банкнот з обігу, є взаємопов'язаними та зазвичай присутні на банкнотах одночасно.

Враховуючи наведене, видається доцільним провести класифікацію пошкоджень банкнот в процесі обігу (рисунок).

В процесі обігу на банкноти діють фактори, котрі за видом енергетичного впливу можна поділити на механічні, хімічні, теплові, електромагнітні. Всі ці механізми діють спільно, посилюючи дію один одного.

Накопичення в процесі обігу забруднювального шару на поверхні банкнот підсилюється механічним впливом різного характеру: згинання, зминання, скручування, тертя, розривання, продавлювання, злам тощо [6, 8]. Внаслідок механічного впливу через зниження жорсткості 
паперу, його структурної цілісності, пошкодження волокон, котрі можуть навіть виокремлюватися з поверхні [13], виникає як загальне зношування банкнот, котре проявляється в збільшенні пористості та шорсткості паперу, зменшенні його жорсткості [8], так і порушення структурної цілісності - такі дефекти банкнот як розриви, прориви, загини, зморщування, заламування кутиків та зміна периметра банкнот, надрив крайки паперу тощо. При цьому збільшення ступеню загального зношування паперу зменшує подальшу здатність банкноти опиратися механічному та іншим впливам.

В результаті дії на банкноти джерел хімічного впливу мають місце процеси адсорбції, абсорбції, десорбції та окислювання, а також фотохімічні процеси (як результат комбінованої дії хімічних та електромагнітних джерел), що відбуваються внаслідок контакту банкнот з газоподібними, рідкими та твердими органічними та неорганічними речовинами, котрі можуть проникати в об'єм паперової основи чи утворювати шар на іiї поверхні. Серед неорганічних речовин на стан банкнот найбільше впливають вода (як пряме потрапляння на банкноту, так і вологість повітря) та кисень атмосферного повітря, оскільки спричиняють старіння паперу та окислювальні процеси в ньому. Вологість повітря $€$ дуже значущим фактором впливу на банкноти, оскільки підвищена вологість повітря не тільки спричиняє прискореному розвитку мікроскопічних грибків (плісняви), але й спричиняє структурні зміни в папері за рахунок видовження волокон целюлози, внаслідок чого утворюється хвилястість банкноти та зменшуються її лінійні розміри. Дуже низька вологість (менше, як 30 \%) призводить до необоротних втрат банкнотним папером структурно пов'язаної води, внаслідок чого він пересихає, втрачає еластичність, стає крихким та ламким [15].

Електромагнітний вплив на банкноти спричиняють джерела природного (сонячне світло) та штучного випромінювання, котрі прискорюють процеси старіння паперової основи банкнот, котрі проявляються в пожовтінні, зниженні міцності та еластичності, виникненні крихкості паперу, а також в змінах колірних характеристик відбитка (зменшенні насиченості) [16], появі плям (фоксингів) внаслідок локальної окислювальної деструкції [17]. Пошкодження банкнот під дією випромінювання широкого спектру (від УФ до ІЧ) посилюється присутністю на поверхні банкноти та всередині структури паперової основи сторонніх домішок, чутливих до світла (забруднення, котрі наявні на поверхні, так і певні включення та речовини, що вводяться в структуру паперу під час виготовлення (захисні волокна, стрічки тощо), котрі до того ж мають специфічні оптичні властивості [18-21]).

Пошкодження банкнот в процесі обігу відбуваються також внаслідок теплового впливу як кліматичного (при якому тепловий вплив відповідає змінам, характерним для природних умов), так і термічного (коли темпера- 


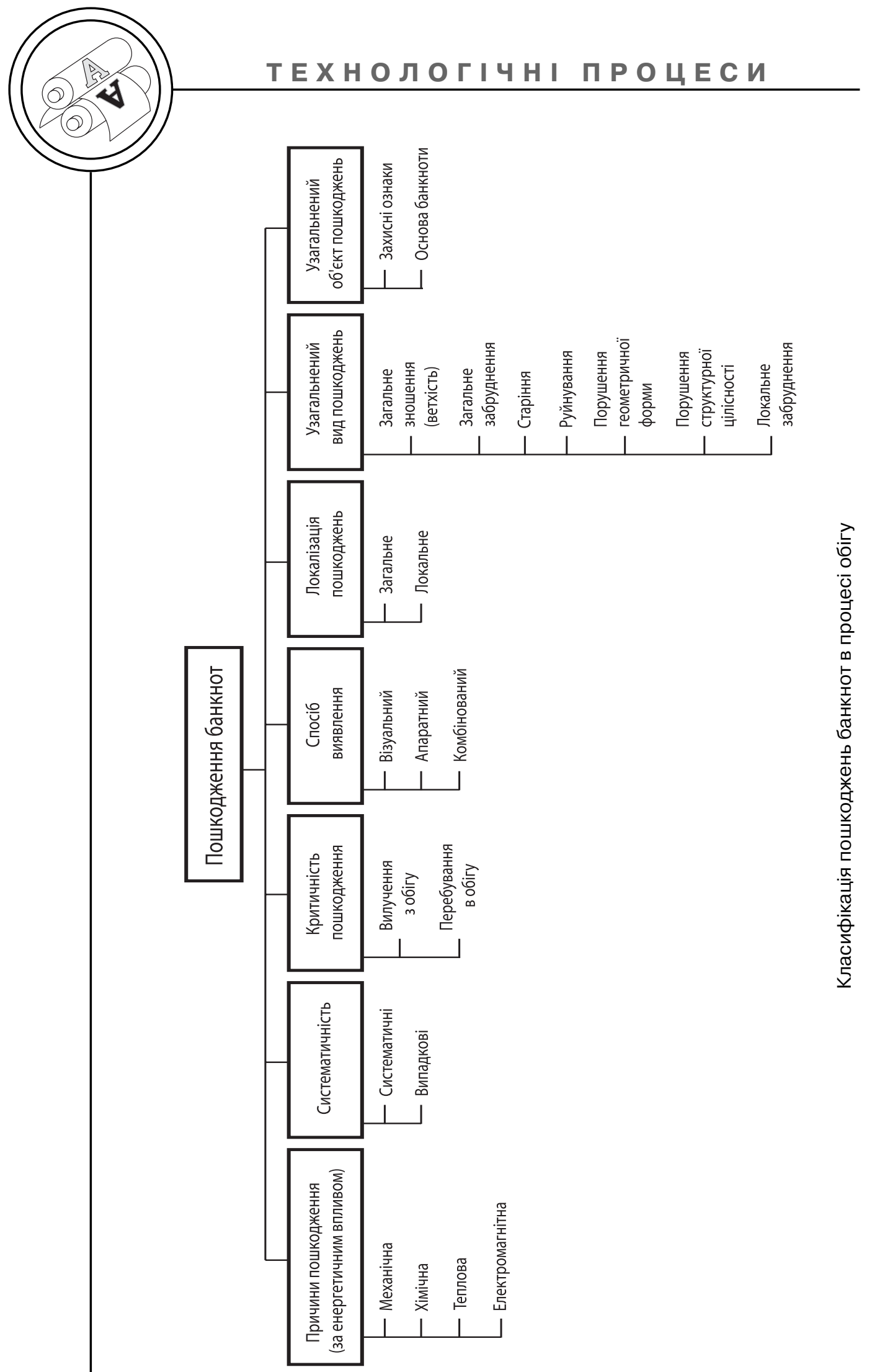


тури є близькими чи більшими за температури термічної деструкції паперу (200-220 ${ }^{\circ} \mathrm{C}$ [22])). Кліматичний тепловий вплив прискорює процеси старіння банкнотного паперу, оскільки підвищення температури на $10^{\circ} \mathrm{C}$ вдвічі прискорює хімічні процеси [13]. Термічний вплив призводить або до повного руйнування банкноти внаслідок згоряння, або до пошкоджень типу локальної термічної деструкції (обгоряння крайки, пропалювання тощо).

3 точки зору систематичності, всі описані вище джерела впливу діють на банкноти систематично, тобто протягом всього часу перебування в обігу, чи випадково. Однак, навіть випадковий вплив може призвести до такого пошкодження банкноти, що вона підлягатиме вилученню $з$ обігу (це може бути значне механічне пошкодження, повна термічна деструкція тощо).

Загалом, з точки зору критичності, пошкодження можна поділити на такі, що дозволяють перебування в обігу, та такі, що призводять до вилучення банкнот з обігу. Критерії, за якими банкноти належить вилучити з обігу, встановлюють нормативні документи. Так, відповідно до нормативних документів Національного банку України $[4,5]$, підставою для вилучення з обігу $€$ відсутність чи втрата властивостей через пошкодження хоча б однієї із захисних ознак, видимих в інфрачервоних, ультрафіолетових променях, чи захисних ознак з магнітними властивостями (інші захисні ознаки перевіряються в разі наявних технічних можливостей). Крім того, банкноти вилучаються через наявність відкритих надривів, більших за нормативні розміри, отворів (відсутні частини будь-де, крім країв) понад 10 мм², за умов відсутності частини вздовж краю чи відсутності кута (площею по-

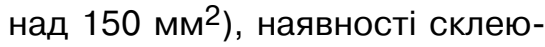
вань (понад 10×40 мм), а також зім'яті банкноти (за умови зменшення довжини на 6 мм, або ширини на 5 мм). Підставою для вилучення з обігу є локальні забруднення (локалізована концентрація бруду у вигляді плям, малюнків, відбитків штампів, колір яких контрастує 3 навколишніми незабрудненими частинами банкноти) певного розміру (від 10×10 мм до 15×15 мм, в залежності від розташування) [4]. Вилучення банкнот через загальне забруднення (розподіл бруду на всій банкноті) та загальне зношення (структурні зміни, пов'язані зі зменшенням жорсткості) відбувається під час автоматизованого оброблення за результатами вимірювань оптичної щільності в певних зонах. Схожі підходи до вилучення з обігу мають центральні банки інших країн [6, 23].

Вилучення банкнот з обігу відбувається банками під час приймання, видачі, оброблення готівки [4]. Сортування $з$ метою виявлення зношених банкнот провадиться як апаратним способом (з використанням спеціалізованого обладнання [24, 25]), так і візуально, а також комбінацією цих способів.

Описані вище впливи спричиняють пошкодження банкнот, котрі за видом (рисунок) можна поділити на групи відповідно 
бруду, насамперед через вплив секрету сальних залоз людини, на всій площі банкноти $[4,7]$ або локалізована концентрація бруду будь-якого походження у вигляді плям, малюнків, відбитків штампів, колір яких контрастує з навколишніми незабрудненими частинами банкноти. Необхідно зазначити, що якщо загальне забруднення утворюється поступово як результат дотиків пальців людини і, зазвичай, супроводжується та підсилюється загальним зношенням, то локальне забруднення може мати місце на банкноті без інших пошкоджень, але призводити до вилучення з обігу (не допускаються локальні забруднення розміром понад 10×10 мм на частинах, що не містять друкованих літер чи зображення, або понад $15 \times 15$ мм на частинах, що містять друковані літери чи зображення [4]);

- старіння - стан банкноти, що характеризується зменшенням еластичності основи банкноти, її крихкістю, ламкістю, пожовтінням [7], котрий виникає під дією часу внаслідок хімічного, теплового та електромагнітного впливу, дія котрих підсилюється механічним чинником;

- порушення структурної цілісності - локальні наскрізні пошкодження основи банкноти;

- порушення геометричної форми - локальні та загальні зміни геометричних розмірів банкноти внаслідок відсутності частини, кута, а також втрати площинності через хвилястість та зім'ятість.

Об'єктом контролю є основа банкноти в цілому, а також захисні ознаки банкноти [5].

Під час приймання, видачі, оброблення готівки контролюють низку ознак зношування та пошкодження [4]: захисні ознаки, видимі в інфрачервоному, ультрафіолетовому діапазоні, захисні ознаки з магнітними властивостями, а також, за наявності технічних можливостей, інші захисні ознаки; механічні пошкодження (надриви, отвори, відсутність кутів та частин, зім'ятість); загальне зношування; локальне та загальне забруднення.

Для досліджень процесів зношування 3 метою оптимізації технологічних процесів виготовлення та раціонального вибору матеріалів для банкнотних відбитків доцільно деталізувати ознаки, котрі перевіряються:

- загальне руйнування зменшення площі банкноти;

- загальне зношення (ветхість) - мікронадриви крайки, потертість, втрата фарби, втра- 
та жорсткості, розпушення паперу (збільшення пористості, шорсткості, товщини, зменшення еластичності (міцності на розрив), а також втрата захисних ознак (див. нижче);

- захисні ознаки, видимі в інфрачервоному, ультрафіолетовому діапазоні, захисні ознаки з магнітними властивостями, тактильні захисні ознаки (інтагліо друк), електропровідність захисних стрічок, флуоресцентні та фосфоресцентні властивості;

- старіння - зменшення еластичності паперу (міцності на розрив), пожовтіння паперу;

- порушення геометричної форми - відсутність кутів та частин, зміна геометричних розмірів через зім'ятість, згин, хвилястість;

- порушення структурної цілісності - механічні пошкодження (надриви, отвори), термічні пошкодження (термічна деструкція крайки (обгоряння) та основи (пропалини)), хімічні пошкодження (хімічна деструкція крайки чи основи);

- локальне забруднення зміна оптичних характеристик (плями, штампи, графіті, хімічне знебарвлення);

- загальне забруднення зміна оптичних характеристик, збільшення ваги.

В таблиці подано ознаки пошкоджень, що контролюються, відповідно до узагальненої класифікації пошкоджень.

Як вже зазначалося, саме загальне забруднення $€$ основною причиною вилучення банкнот з обігу, тому методам його контролю приділяється велика ува- га. Тут до ознак, що контролюють, належить зміна оптичних характеристик банкнот - зміна колірності, що контролюється візуально персоналом, зміна оптичної щільності [4], вимірювання видимого світла, відображеного від банкноти [8], спектральні характеристики банкнот в діапазоні 380-740 нм [8, 13]. Існують й більш складні методики визначення забруднень ультразвукові та рентгенівські дослідження [8], але саме оптичні характеристики, що вимірюються як під час наукових досліджень [6-8, 13, 15], так і під час оброблення готівкової маси [23-26], є основними.

\section{Висновки}

1. В роботі на основі аналізу процесів, що відбуваються під час обігу банкнот, а також факторів зношування банкнот розроблено класифікацію пошкоджень банкнот в результаті зношування. В якості основних класифікаційних ознак запропоновано розглядати причини пошкоджень (за видом енергетичного впливу, що спричиняє зношування), систематичність та критичність пошкоджень, спосіб виявлення, локалізацію, об'єкт контролю, узагальнений вид пошкоджень та ознаки, що підлягають контролю.

2. Проведено деталізацію пошкоджень банкнот в процесі зношування, спрямовану на використання її під час вивчення процесів зношування з метою оптимізації технологічних процесів виготовлення та раціонального вибору матеріалів для банкнотних відбитків. 


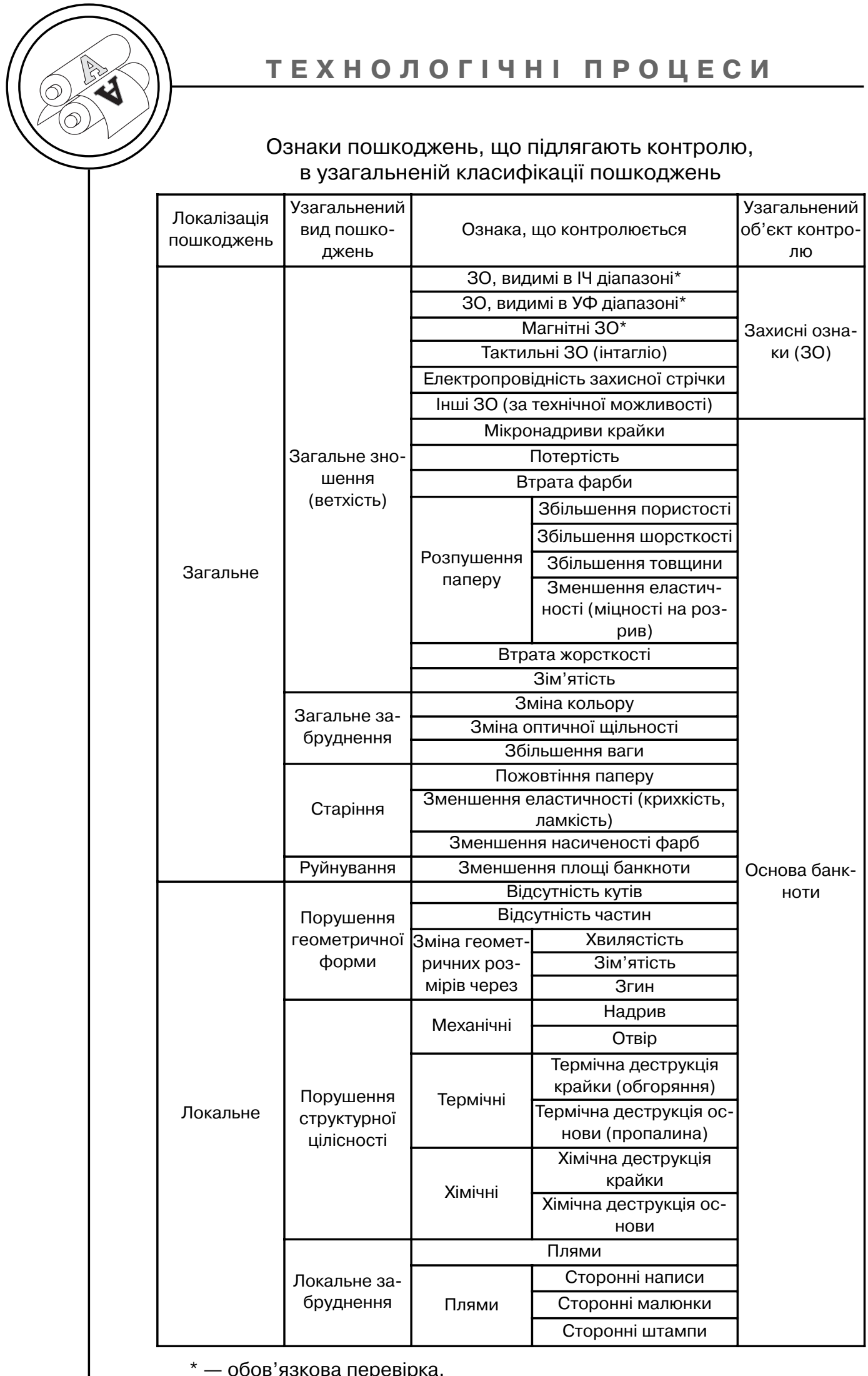


Розроблена класифікація пошкоджень банкнот дозволяє систематизувати відомості щодо по- шкоджень в результаті зношування та враховувати їх для організації досліджень зношування банкнот.

1. Coppelia Marincovic, Kathy Pritchard, Marc Binder, Nuno da Silva. Life Cycle Assessment of Canada's Polymer Bank Notes and Cotton-Paper Bank Notes. Final report. - May 27, 2011. - Офіційний сайт Bank of Canada. Шлях доступу : http://www.bankofcanada.ca/wp-content/uploads/2011/ 06/Life-Cycle-Assessment-of-Polymer-and-Cotton-Paper-BankNotes_opt.pdf. 2. Torsten Meuer, Jerome Martin. The Eurosystem's efforts in the search for a longer lasting banknote. - Billetaria. International Review on Cash Management. Issue 9, April 2011. - P. 22-24. 3. Jerome Martin. Measuring the lifetime of euro banknotes with a circulation trial. - Proceedings of Banknote'2011. The definitive forum on emerging trends and leading technologies in the banknote industry. - Washington, USA, 11-14 July, 2011. 4. Інструкція про ведення касових операцій банками в Україні (Затверджено Постановою Правління Національного банку України від 01.06.2011 № 174). 5. Правила визначення платіжності та обміну банкнот і монет Національного банку України (Затверджено Постановою Правління Національного банку України від 17 листопада 2004 р. N 547). 6. Jan-Mark Geusebroek, Peter Markus, Peter Balke. Learning banknote Fitness for Sorting. - DNB Betalingsverkeer. Cash Policy Department, De Nederlandsche Bank NV. - Шлях доступу : http://www.dnb.nl/binaries. 7. From Fit to Unfit: How Banknotes Become Soiled. - Peter Balke, Cash Policy Department, De Nederlandsche Bank NV. - Шлях доступу : http://www.dnb.nl/binaries. 8. Tom Buitelaar. The Colour of Soil. - DNB Cash Seminar 2008/ Amsterdam, 28-29 February, 2008. - De Nederlandsche Bank NV. - Шлях доступу : http:// www.dnb.nl/binaries. 9. Fernando Leon, Andreas Walter. Varnishing solutions for a long-lasting banknote. - Billetaria. International Review on Cash Management. Issue 9, April 2011. - P. 25-27. 10. Ana Maria Gonsalez, Diego Schweckandt. Test on long-life paper. - Billetaria. International Review on Cash Management. Issue 9, April 2011. - Р. 32. 11. Багатошаровий захисний матеріал та спосіб його виготовлення [Текст] / КАУТТУА ПЕЙПЕР МИЛЛ ОЙ, АЛЬСТРОМ КОРПОРЕЙШН. - Фінляндія. - 20040806. - 11.06.2004. 12. Захисний елемент для цінних документів [Текст] / Киричок Т. Ю., Малкуш Н. Л., НТУУ «КПІ». - Патент України № 56769. - Опубл. 25.01.2011. 13. New Soiling Test Method: Anti-Dirty Fingers. - Peter Balke, Cash Policy Department, De Nederlandsche Bank NV. - Шлях доступу : http://www.dnb. $\mathrm{nl} /$ binaries. 14. LongLife. The banknote paper that «lives» longer. - Офіційний сайт фірми Louisenthal. - Шлях доступу : http://www.louisenthal.com/en. 15. I. L. Pedersoli, F. J. Ligterink. Spectroscopic characterization of the fluorescence of paper at the wet-dry interface // Restaurator. - 2001. - V. 22. Р. 133-145. 16. Эдкок Эдвард П. Основные правила хранения и использования библиотечных фондов, разработанные ИФЛА : пер. с англ. / Междунар. федерация биб. ассоц. и учреждений. Основная программа «Сохранность и консервация». Совет по библ. и информ. ресурсам; сост. и ред. Э. П. Эдкок, при участии М.-Т. Варламоф и В. Кремп. - М. : Рудомино, 1999. - 72 c. 17. K. Greve. Foxing - Causes and Questions. - Conservation 
without Limits // IIC Nordic Group XV Congress. Helsinki, 23-26 August, 2000. - Helsinki, 2000. - Р. 55-62. 18. Киричок П. О. Методи захисту цінних паперів та документів суворого обліку [Текст]. Монографія / П. О. Киричок, Ю. М. Коростіль, А. В. Шевчук. - К.: НТУУ «КПІ», 2008. - 368 с. 19. Офіційний сайт фірми Louisenthal. - Шлях доступу : http://www.louisenthal.com/en. 20. Офіційний сайт фірми Crane. - Шлях доступу : http://www. cranecurrency.com. 21. Security features integrated in banknote paper. Billetaria. International Review on Cash Management. Issue 9, April 2011. Р. 38-39. 22. Смирнова Е. Г. Влияние состава по волокну на термическую деструкцию бумаги до и после старения / Е. Г. Смирнова // Химия растительного сырья. - 2011. - № 1. - С. 175-178. 23. Mariano Martinez, Eduardo Kropnick, J. Dario Negueruela. Mechnical banknote sorting: an empirical study. - Billetaria. International Review on Cash Management. Issue 6, October 2009. - P. 16-19. 24. Masahiro Takagi. Toshiba's banknote processing machines. - Billetaria. International Review on Cash Management. Issue 4, October 2008. - P. 24-25. 25. Francisco Cantero. Banknote authentication devices. - Billetaria. International Review on Cash Management. Issue 8, October 2010. - P. 21. 26. Banknote Processing Systems. Офіційний сайт компанії Giesecke \& Devrient. - Шлях доступу : http://www.gi-de.com/ en/products_and_solutions/products/banknote_processing_systems/banknote-processing-systems.jsp. 